1015

\section{高血圧及び虚血性心臓血管病と眼底血管計 測値との関連}

O国重 宏, 矢野勝嬖, K.G.Johnson 加藤蕌夫

(A B C C)

咋年の本学会で予備調查結果を発表したが，引き続き， 広島A B C C で実施中の成人健康調查標本中，40 69才 迄の男子300名に，マミヤミラーレンズ眼底カメラを使 用して，両眼，乳頭中心，上下耳側の各三枚，カラースラ イド写真撮影を行なった。全スライドは，血管計測に倛 する為，付属の補正逆投影装置にて，20.3 cm×21.7 $\mathrm{cm}$ の 黑白プリントに引き伸した。対像者は，少なくとも 6 年 前から，2 年每に詳細な医学的検查を受けたもので，そ の間の資料を基礎にした。スライドによる肉眼所見は， 医師 2 名の判定により，昭和 $36 \cdot 37$ 年厚生省成人病基礎 調查に用いられた分類を若干変更したものに記録し, 計 測では，計測血管の選択，乳頭径，乳頭辺縁から 1 及び 2 乳頭径点の主細動静脉径，第 1 細動静脉分枝点までの 長さ等を調べた。所見は，夫々心臟血管病に関する臨床 成績と比較したが, 特に血压, 年令と計測による狭細所 見について，我々の標本で次の様な結果を得た。WHO の基凖を参考䎲すると，主細動静脉のいずれかに不適と されるものが夫々約 2 割, 共に不適であるものが約 1 割 その他同一 sector として, 動静脉莫対此出来ないもの 等，てれまで，何等かの所見群に入られていたものが計 測の対象汃ら除外された。

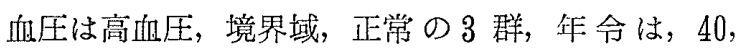
50, 60 才台の 3 群に分けて夫々, 1 乳頭径点での $\mathrm{A} / \mathrm{P}$, $\mathrm{V} / \mathrm{P}, \mathrm{A} / \mathrm{V}$ を見ると，明らかな相関を有するものは， 我々の対象では見出せず，収縮期，拡張期血圧と $\mathrm{A} / \mathrm{V}$ と

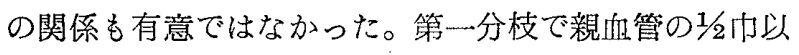
下になる主分枝血管は殆どなく，血管計測上，狭細所見 を考学る時, 血管計測点, 比較血管の選択, 焦点のあっ た中心部のみに限られる計測值, 血管外径の計測である 事など，今後の問題がある様に思われる。

\section{6 眼底情報の層別化について}

秋山房雄, 根岸龍雄, ○安見道子

(東大成人保健)

見藤隆子

(東大保健管理)

演者らは, 第22回公衛学会総会以来, 眼底情報の情報 科学的考察を加えてきたが, 眼底情報は昨年の第36回衛 生学会で発表したように，各所見を構成する所見要素で
とに考察した方が，その情報量の獲得は大きいととが分

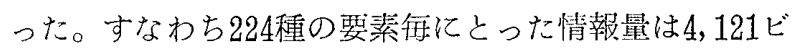
ットであるのに対し，Sheie のH所見のみに注目すれば 6, 640ビット, Sheie のS所見のみについて考光れば, B, 785 ビット，KW分類による情報のエントロピー量は 5 , 315 ビットであり，所見要素でとに钼察するととが，い か汇必要かについて論じたが，各所兒要素群を情報の層 と考光た場合の層別化の問題について論ずる。すなわち SheieS 所見, SheieH所見, KW 所見, および全眼底所

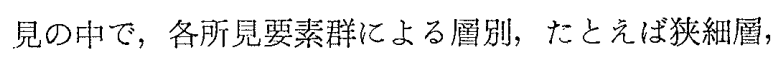
血管不同層，出血層なぞの各層別の占める割合について 計算し, 各所見要素群の層としての働きについて報告し, ぞの層が最も重要な所見であり，ぞの程度の層の厚さか について論ずる。たと党ば, Sheie H所見については, 出血情報が情報量を最も多くもってはいるが，不同情報 の層が最も大きい。

\section{7 高血圧予防の住民の自主的保健活動と公襌 簓生従事者の役割}

$$
\begin{array}{ll}
\text { 松井清夫, 坂本 弘 } & \begin{array}{r}
\text { (三重県大街生) } \\
\text { ○山本虽美子 }
\end{array} \\
\text { (三重県久居町役場) }
\end{array}
$$

高血圧対策沈いて，食塩過剩摂取や寒冷頻回啕露の ような個々の対策をたてるのでなく，「全生活の合理 化」をめざした「新しい村づくり」が必要であるてとは 諸家の指摘するとてろであるが，新しい村づくりの力動 に関する研究は少ない。住民自身が高血圧対策として農 休日制をとり上げ，部落活動として展開した事例につい て，実施にいたる経過をすで報告した。今回は農休日 制実施によりもたらされた住民の健康および生活の変化 について報告するとともに，住民活動に対する公篦衛生 從事者の役割について考察しようとする。

対㞘地区は三重県中部の交通不便な人口約 800 名の無 医地区である。昭和38年より，高血庄刘策としての農休 日制（月1回）が住民の自主的活動としておてなわれてい る。農休日のは保健対策協議会が計画し, 初期は公民館 などで全住民参加行事が組まれたが，次第に各家庭での 休息日としてすですようにきりか党つつある。

実施前と昭和40年度との比較では, 循環器系医療受部 が低下し，血圧異常者も減じた。さらに，結核住民検跈

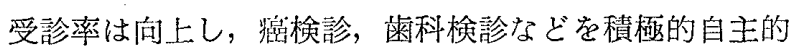
に要望し，䨋施するにいたった。また，消費生活の変化 や野菜栽培の増加がみられた。

乙の間, 公葲衛生彷事者は定期的血圧測定, 住民要望 